\title{
Motor Roll Pin Device
}

National Cancer Institute

\section{Source}

National Cancer Institute. Motor Roll Pin Device. NCI Thesaurus. Code C50103.

A pin that is formed as a rolled sheet and acts to provide a retaining force on the part

through which it is inserted. 